\title{
Sustainable In-situ Jute Retting Technology in Low Volume Water using Native Microbial Culture to Improve Fibre Quality and Retting Waste Management
}

\author{
Asesh Kumar Ghorai* and Asim Kumar Chakraborty
}

\author{
ICAR-Central Research Institute for Jute and Allied Fibres, CRIJAF, \\ Barrackpore, West Bengal, India \\ *Corresponding author
}

\section{Keywords}

Jute (Corchorus olitorius), Microbial Culture

Article Info

Accepted:

10 October 2020

Available Online:

10 November 2020

\section{A B S T R A C T}

Water retting of whole jute (Corchorus olitorius L.) plant is convenient to the majority of farmers. Jute bundles are extensively retted in isolated stagnant inland freshwater bodies, often having insufficient water, during the months of August-October in the Indo-Bangla subcontinent. It leads to transportation expense, improper retting with low fibre quality, complete loss of huge organic retting residue and transitory deterioration of the aquatic environment affecting local ecology. Water scarcity due to climate change has aggravated jute retting. This article details a comprehensive retting technology where1-1.35 m deep circular or rectangular lined (tarpaulin/silpaulin) or unlined (in clay soil) micro-pond of area $80 \mathrm{~m}^{2}$ (i.e., 2 decimal) is sufficient for retting a jute plot of 0.135 ha and that of $130 \mathrm{ma}^{=}$(i.e., 3.5 decimal) for 0.340 ha harvest area, in a batch. Staggered jute sowing or harvesting at 10-15 days' interval enables two more successive batch rettings in a pond with shorter retting time and improved fibre quality. Water requirement in it is only $431 \mathrm{~kg}^{-1}$ of good quality fibre, compared to $693 \mathrm{l} \mathrm{kg}^{-1}$ in traditional retting. It is suitable primarily for small and marginal land holdings. Also described modifications on local retting methods addressing practical difficulties. Demonstrations at farmers' field of this technology held regularly since 2009 found its higher acceptability. Using ground water or rainwater under deficit rainfall, it produced desired golden coloured and lustrous fibre in 15-30 days in a hygienic extraction setting. It abolished usual labour requirement of 30 man-days ha ${ }^{-1}$ or more to carry jute bundles to distant retting spots. In a micro-pond of 2 decimal area for retting 1 acre jute, with an initial investment of Rs 15900, its benefit-cost ratio is envisaged at 1.28:1, signifying a substantial economic return in the course of 5 five years. In a new integrated farming system (IFS) model, it sustained jute retting in low volume water, strengthened farm income from improved fibre quality, conserved organic manure (10-15 bags per year), diversified production by optimizing resource use in the production of rice, vegetables and fish and reduced environmental pressure. Additionally, a well-developed network of these tanks can support to improve groundwater recharge, provide lifesaving irrigations, save crops from early water logging stress and in-situ composting of agricultural residues during dry months.

\section{Introduction}

Jute (Corchorus olitorius L.) is the cheapest natural industrial fibre of great economic importance to South Asian countries. The final important management step of a wellraised jute crop is the process of separation and extraction of fibres from the bast layer of 
jute stem by retting process (Dasgupta et al., 1976; Majumdar and Day, 1977). Water retting is the convenient process for the majority where plants undergo microbial decomposition. It is followed for whole plant retting and ribbon retting. In ribbon retting, ribbons from harvested plants are mechanically peeled off to produce fibre with better colour and lustre with reduced water requirement (Banik et al., 2003). However, it is yet to gain popularity among the farmers as ribboning result in loss of fibre and crushed jute stems. Further, non-availability of efficient and farmer-friendly ribboner or bulk ribbon retting process and high cost compared to conventional retting have resulted its poor adoption (https://greenwatchbd.com/ribbonretting-of-jute-not-yet-popular-in-rangpur/). Majority of the growers traditionally submerge jute bundles extensively in derelict stagnant inland water bodies (Ahmed, 1992), like ditches, ponds, roadside canals, having insufficient and muddy water, away from residential places, during the months of August-October, coincidentally overlapping with the spawning season of native freshwater fishes (Mondal et al., 2008). Oftentimes these water bodies are used for repetitive retting (Figure 1A) in successive batches (Jarman, 1985). These cause disadvantages of improper (under and over) retted fibre, diminished colour, luster (Figure 1B) and strength of fibre, loss of huge organic retting waste (FAO, 1998; Banik et al., 2003), substantial expense and drudgery in transportation of the bulky material from the field to the retting spot.

Climate change has also triggered recurrent temporal and spatial scarcity of jute retting water (Ghorai et al., 2010). In extreme scarcity, often farmers dump jute bundles in ditches wait for good rain or forgo to care further. A local practical problem in alluvial soil is that farmers daily irrigate shallow and bare jute retting pits $(60-90 \mathrm{~cm}$ depth) with groundwater to maintain water level of the pits for the entire retting period (30 days) costing Rs. $7500 \mathrm{ha}^{-1}$. Shortage of quality fibre, a recurrent phenomenon in Indian jute industries, has led to import fibre from Bangladesh. In spite of much research, jute growers continue to face various practical difficulties in implementing the proper procedure for retting. Microbes involved in retting have been widely reviewed (Das et al., 2014). Abundance of these microbial communities are reported in soil and muddy water of any natural retting site (Munshi and Chatoo, 2008; Jarman, 1985). Introduction of native and synthetic activators provide desired nutrition to promote microbial growth and activity for faster retting (FAO, 1998; Ahmed and Akhter, 2001; Ghorai et al., 2013 and Das et al., 2014).

Within a short period following steeping of jute bundles, pond water undergoes sharp depletion in dissolved oxygen (DO), increase in biochemical oxygen demand (BOD) load, free carbon dioxide level, buildup of ammoniacal compounds, increase in microbial load and water discolouration. Decomposition of huge biomass results in the generation of pollutant waste liquor with floating scum on water surface and release of abhorrent gases, mostly methane (Banerjee and Dastidar, 2005), stressful conditions to the aquatic system (Haque et al., 2002), lowered native fish diversity even in relatively large water bodies (Ghosh et al., 2015) and caused fish mortality (Mondal et al., 2008). The fish mortality effect would have been greater for retting in small closed retting system (Dasgupta et al., 2006). Water pollution due to jute retting, though transitory and fully biodegrade at a slower pace without adding any toxic substance, is initially harmful, that lessens over several months to subside gradually to become hygienic (Kumar et al., 2015; Haque et al., 2002; FAO, 1998) and biodegraded waste is beneficial to fishes. 
Voluminous retted wastewater is nutrient-rich though diluted. Retted wastewater is nutrientrich. Again, at the time of fibre extraction and washing, a great amount of decomposed plant parts are released into the water in the form of suspended solids (Haque et al., 2002).

Thus, for jute retting in stagnant water, the crux of the problem is water management at two fronts, (i) proper retting of plants and (ii) effective utilization of voluminous retted water. It needs development of alternative retting techniques with better water management strategies of low-cost retting in low volume water (Ghorai et al., 2003a; FAO, 1998), conservation of retting residues (Banik et al., 2003) and to reduce environmental impacts of retting waste on local water bodies (Thi da et al., 2020; Ghosh et al., 2015) to overcome these disadvantages.

Considering these issues/objectives, in-situ jute retting studies were carried out at ICARCRIJAF, Barrackpore, India, during 2009. 2012 in low density polyethylene (LDPE) sheet lined micro-pond in 1:1.25 v/v water (groundwater and rainwater) using native microbial retting inoculum. This method was validated and perfected through a number of trials at farmers' field across 4 districts of West Bengal, India, during 2015-2019 in collaboration with the Directorate of Agriculture, Government of West Bengal. Also held field level demonstrations across the country through AINP JAF centers during 2012-14.

Most of the farmers of India and Bangladesh have small and marginal land holdings (Mandal, 2016; George, 2015) and low resources. Since planned community retting structure runs the risk of feud and decisionmaking, it is practical to consider a micropond, a self-sufficing and sustainable retting unit, for an individual farmer with 0.135 ha (1 bigha or $1 / 3$ acre) jute area.

\section{Materials and Method}

Different components of the in-situ retting technology are detailed in the following under few sub-titles and a workflow diagram (Figure 14) summarises the materials and sequential order of activities for assured jute retting with microbes collected from local retting site.

\section{Construction and design of in-situ micro- pond}

A 1-1.35 m deep circular or rectangular lined micro-pond of area $80 \mathrm{~m}^{2}$ (i.e., 2 decimal including bund, Figure 2) is sufficient for retting a jute crop area of 0.135 ha (i.e., 1/3 acre) and $130 \mathrm{~m}^{2}$ (i.e., 3.5 decimal excluding bund) for 0.340 ha (i.e., $2.52 / 3$ acre) of jute area. The micro-pond was dug using JCB machine at the lowest corner of the jute field to facilitate natural collection of runoff water (rainfall during the months of June-July) from the jute field. A pre-constructed field drain is connected to the micro-pond for collection of runoff water. A $130 \mathrm{~m}^{2}$ micro-pond with 1.35 $\mathrm{m}$ depth (lined with $53 \mathrm{ft} \times 43 \mathrm{ft}$ size silpaulin/tarpaulin sheet, Figure 1C and 1D) can harvest rainwater upto 175000 litre. For a circular micro-pond, floor diameter and top internal diameter will be $8 \mathrm{~m}$ and $10 \mathrm{~m}$, respectively. The tank depth will be $1.20 \mathrm{~m}$ deep from ground level having a raised embankment of 0.30 to $1 \mathrm{~m}$ height around the pond. Bund height of $1 \mathrm{ft}$ is the most convenient for fibre extraction. A gentle slope is maintained at the lower end of the micropond for drainage of tanned wastewater rich in ferrous tannate, with a spell of good rainfall runoff during retting period.

Pipe installation betters pond water management, enables water storage and controlled diversion of the nutrient-rich retted water away from the pond into a desired cropped area in a safe and hygienic way. It 
reduces pond siltation, clogging, overcomes inconveniences of an earthen channel and reduces pond maintenance expenses. PVC cap or plug fitting at all the three open ends of the pipe control water flow.

\section{Lining the pond with Silpaulin/tarpaulin sheet}

If the soil has 3-4 m deep clay layer, then the pond may not require lining (Figure 3A). In coarse soil, it is lined with silpaulin/tarpaulin sheet (250 GSM, longevity 7-15 years). Before lining, the pond floor and its sides are treated with insecticides (viz., $500 \mathrm{~g}$ of Furadon $3 \mathrm{G}$ ) and along the sides (1 m wide) of the embankment inserted 1 celphos tablet deep into each soil hole $(2 \mathrm{~cm}$ deep and $5 \mathrm{ft}$ afar) and closed the openings with wet mud. These preventive measures save the lining from damage by rodents. Bamboo pegs $(2 \mathrm{ft}$ long and 20-30 in numbers) are firmly implanted into soil $(0.5 \mathrm{~m}$ away from the outer periphery) of the embankment. Then the sheet is laid squarely covering the pond floor and its embankment (Figure 3B). To fix the sheet in position, it is tied with ropes to the bamboo pegs through the ' $\mathrm{O}$ ' rings of the silpaulin/tarpaulin sheet. These sheets are prone to tear and may need sealing of punctures. During steeping jute bundles are handled carefully at the pond. Straw bundles placed over sheet act as buffer and save the sheet from likely damages. Ramming the sharper cut bases of bundles on hard surface help to blunt their sharpness and avoid damage to the silpaulin/tarpaulin sheet.

\section{Jute retting with groundwater in shallow rectangular pit}

Under acute retting water shortage, some farmers of West Bengal, traditionally dig 60$90 \mathrm{~cm}$ deep shallow pits (Figure 4A) on puddled soil of area $130 \mathrm{~m}^{2}$ to accommodate jute plants of $1 / 3$ acre $\left(1333 \mathrm{~m}^{2}\right)$. They irrigate the pit daily for an hour till the completion of retting (25-30 days). It was improved by lining mud floor with tarpaulin sheet (250 GSM, $36 \mathrm{ft} \times 30 \mathrm{ft}$ ) (Figure 4B) to save percolation and seepage losses of water, requiring 2-4 irrigation-hour in as many days. Thus it saved water by more than $90 \%$ and produced quality fibre. In the event of scarcity of land, the same procedure can be followed in roadside ditches (Figure 4E) by creating strong septum at desired intervals, lining with silpaulin/tarpaulin sheets, using harvested rain or ground water and to accelerate retting adding pre-retting effluent or suitable retting culture, arranging bundles (Figure 4C) and steeping (Figure 4D) to obtain better fibre.

\section{Native retting culture development}

Four to five days before steeping, the native microbial retting inoculum was developed in knee deep water of the micro-pond. In micropond, added $100 \mathrm{~kg}$ soil from a locally known retting site which contain sufficient retting propagules and supplemented with activators of $100 \mathrm{~kg}$ chopped off tender sunnhemp plants (30-40 days old), $1 \mathrm{~kg}$ molasses, $500 \mathrm{~g}$ of fertilizer (N:P:K::10:26:26) and $1 \mathrm{~kg}$ Ammonium sulphate (Figure 5B). For this purpose, sunnhemp (500 g seed) was sown around jute field (35-40 days before jute retting) as boarder crop or in the pond embankment (Figure 5A). The culture attains active state by 4-5 days. Applied molasses (byproduct of sugar industry) acted as a carbon source for the growth of fungi and production of pectinase through submerged fermentation process (FAO, 1998). For a newly dugout micro-pond in clay soil fed by groundwater, retting culture development was needed only for the first year.. Ground water normally has low microbial counts. Application of low-cost and locally available nitrogenous materials such as urea (at 0.01$0.1 \%$ green weight basis) is recommended along with the microbial cultures such as 
retting effluents (2.5-10\%). Similarly, placing a few plants of sesbania into the ret accelerates retting (FAO, 1998).

\section{Harvesting, sorting, bundling and defoliation}

Jute plants are cut at the ground level at 100120 days after sowing (DAS). Harvested plants are grouped into thicker and thinner plants or according to plant height. These are tied separately into bundles $(15-25 \mathrm{~cm}$ diameter at the butt-end, i.e. 70-100 plants) and retted separately for uniform retting and ease in fibre extraction process (Haque et al., 2001a;Jarman, 1985). Thicker plants require longer retting time (Jarman, 1985). Again, top parts of the jute plant ret in shorter time than bottom parts. Gentle malleting the basal part $(40 \mathrm{~cm})$ of the jute plant reduces retting time to a more or less uniform retting of the whole stem and improves fibre quality (Haque et al., 2001b). Jute bundle are stacked for 3-4 days and are shaken afterwards for defoliation. For stacking in a line, jute bundles are successively laid on the ground covering the bare part of a set of bundles by the leafy top of another set and when bundles are exhausted, finally the bare parts are covered with grasses or straws to avoid sun-drying. Defoliation reduces avoidable organic retting load, weight of bundles, enhances microbial activity as stem tissues shrink and cells rupture due to temperature rise in covered stacks and recycling of nutrient-rich leaves (Jarman, 1985; Ghorai et al., 2003b; Ghorai et al., 2014). Chopping off plant top part (10-15 $\mathrm{cm}$ ) improves further in handling of jute bundles and retting process (Jarman, 1985) and recycling of them (Ghorai et al., 2003b; Ghorai et al., 2014).

\section{Jute steeping, jak preparation and interim management}

Defoliated jute bundles are arranged in 2-3 alternate layers, one over the other. The steps followed are detailed in Figures 6A to 6E. Plant tops ret earlier and become source for supplying retting inoculum to the bases which take more time to ret. Few small bundles (4 inches diameter) are placed in between layers (Figure 6B) to maintain space in between layers, avoid over-congestion of bundles and facilitate uniform microbial retting activities in the sandwiched plants.

Then large jute bundles are interlocked with ropes made of chads. After 'jak' arrangement, jute bundles are covered with stale rice straw or water hyacinth to prevent drying in direct sunlight. In the next step, and 5-6 bamboos are placed across the bundles (Figure 6D) for uniform load (of soil-filled cement bags) distribution and weighed the jak with soilfilled cement bags (Figure 6E) over the bamboos to put the jak under water $(5-10 \mathrm{~cm})$ till completion of retting. Undamaged old cement bags (40-55 in numbers) filled with sand or stone or soil, are placed over the jaks. Water-filled mega plastic bags (Figure 7) were also found effective for steeping jute bundles. Fresh banana stems and fresh wooden $\operatorname{logs}$ cause discolouration of fibre. Finally, filled the pond to the brim with groundwater (Figure 6F). Jute bundles are kept submerged nearly 5-10 cm below water surface throughout the retting period. Strict vigilance has to be kept so that the jak remains under water for the entire retting period and for this purpose irrigated when needed. Fourth day (after steeping) onwards, taken care to drain out and runoff tanned water of the pond though a channel $(10 \mathrm{~cm}$ dep) at the lower slope end of the pond during the spells of rains. After 8-10 days of steeping, jute bundles are trampled for the escape of accumulated undesirable gases into for quicker retting.

Maintained favourable condition of rettingwater (quality and volume) during the retting period. Provisions (pipes or channel along the bund) made for inflow of water into the pond 
and to drain out retted waste water from the pond, to bring down the load of decomposed substances through slow and partial surface runoff and directed the flow to irrigate an adjacent crop field (Figure 10F).

\section{Completion of retting}

Since the tenth day after steeping, required regular testing of 10-15 plants of different jute bundles to ascertain completion of retting so as to avoid improper (under or over) retting by 'test and feel' method, whether fibres gets loosened easily from stems. Farmers usually test stems at $45 \mathrm{~cm}$ above the plant bases with two fingers to see whether fibres slips out of stem on small pressure. The retting duration varied according to age of jute plants and environment of the micro retting tank, especially water temperature during the retting period. Using groundwater in micropond, 123, 130 and 145 days old jute plants retted in 14-15, 20-25 and 27-30 days, respectively. Subsequent retting in the second and third batch was much faster (12-20 days) depending on the age of jute plants.

\section{Fibre extraction}

Before jute extraction the tanned (ferrous tannate rich) water (Figure 8A) was drained out through a 1-foot-deepchannel and it was diverted to adjacent rice field. The pond was refilled to the brim with fresh groundwater. Another way is to drain out retted water through the lower slope in one side of the pond and pumping fresh groundwater into the pond through the other side, simultaneously, for an hour during extraction (Figure $8 \mathrm{~B}$ and 8C). This simulates the slow moving water (Bhattacharyya, 1974; Ghosh and Bose, 1973) as that of streams and rivers to obtain quality fibre from jute retting sites. Otherwise, the ferrous tannate present in retted water gets converted to ferric tannate no sooner the fibres are taken out of water than the fibre blackens by allowing to come in contact with air during fibre extraction. Hence, simultaneously draining out of retted water and replenishment with freshwater is of prime importance to obtain golden colour and lustrous fibre. In the experiment, added a lime solution ( $2 \mathrm{~kg}$ lime in 15 litre water) along the periphery of the pond where persons squatted for extraction to prevent skin infection from retting water during fibre extraction.

Jute fibre is extracted by single plant extraction method, squatting comfortably over the lined bund (Figure 8D) in a moderately hygienic condition. Whereas, in conventional extraction process, the site is appalling, muddy and unhygienic. With provisions of drainage from the pond, golden colour, strong and lustrous jute fibre (Figure 8E) was obtained. In case of barky bottoms, gentle malleting at the bases during extraction remove barks to improve fibre quality. Generally, jute fibres are dried in household courtyards surrounded by bushes and plantations which delay the drying process resulting in fibres of weaker strength. For quick drying, it is better to dry at the pond embankment on bamboo scaffolds in sunny and relatively quiet days, avoiding windy days.

\section{Results and Discussion}

\section{Reduction in water requirement}

This method required 130 of freshwater $(\mathrm{v} / \mathrm{v}$ : $1: 1.25)$, i.e., $43 \mathrm{l} \mathrm{kg}^{-1}$ of good quality fibre, nearly one sixth of water requirement in conventional retting method, $2080 \mathrm{~m}^{3} \mathrm{ha}^{-1}$ (v/v: 1:20), i.e., $693 \mathrm{l} \mathrm{kg}^{-1}$ of fibre. Retting is assured by the use of the native retting culture developed in the micro-pond 4 days ahead of jute steeping. After 5-6 consecutive rainy seasons (in alluvial soil) the retting tank lining can be avoided, as jute retting residues and siltation from runoff water block the soil pores and minimizes the percolation rate. 
Maximum and minimum temperatures of retting water of micro-pond, usual retting pond and air during retting

In the experiment, recorded maximum (2.00 $\mathrm{PM})$ and minimum (8.00 AM) temperatures of retting water at $5 \mathrm{~cm}$ and $10 \mathrm{~cm}$ below water surface during the retting period (Table 1) for the traditional pond ( 20 decimal area) and micro-pond ( 2 decimal area). The $\mathrm{pH}$ of the retting water varied between 6.28 and 6.42. It showed that micro-pond water was relatively warmer to traditional pond at all water depth throughout the retting period. It received a total of $117.6 \mathrm{~mm}$ rainfall in 14 days to drain out retted water.

\section{Polyculture in and around the micro-pond}

Open Spaces in and around the pond were exclusively engaged for retting and fibre extraction purpose for a period of $1 \frac{1 / 2-2}{2}$ months, steeping to fibre extraction days. Otherwise, it extremely inconvenienced steeping (Figure 11A) and fibre extraction (Figure 8D and 8E) operations for piling up of large amount of jute bundles, wet jute sticks (1.5-1.7 $1 \mathrm{ac}^{-1}$ in number, each $10-12 \mathrm{ft}$ long) and wet fibre bundles, pond surrounding got thoroughly drenched and soil puddled during extraction needing another 15 days wait before growing crops, damaged established crops (Figure 11B) and pond water also unsuitable for fish farming. In such a small and closed retting system with low volume $(1: 1.20 \mathrm{v} / \mathrm{v})$ water, it is most unlikely that any fish will survive during the jute retting period (Dasgupta et al., 2006; Ghosh and Biswas, 2015). Fish farming during jute retting period was not attempted in the experiment. Observing the extreme operational inconveniences in the presence of established crops in the first year of the experiment, crop growing was altogether abandoned (except few dioscorea plantations) later on for $1 \frac{1}{2}-2$ months of retting days in the experiment. With this exception, it was utilized throughout the year for growing vegetables in the bunds or dried pond floor, rice on pond floor and fish farming on pond water during October to July, depending on water availability. It was naturally filled by rainfall and surface runoff with the onset of monsoon (in the month of June) and maintained optimum water level until the middle of November.

Table.1 Daywise maximum and minimum water temperature of micro-pond and natural pond at two depths and ambient temperature during retting period in the year 2011

\begin{tabular}{|c|c|c|c|c|c|c|c|c|c|c|}
\hline \multirow[t]{3}{*}{ Date } & \multicolumn{5}{|c|}{ Maximum Temperature } & \multicolumn{5}{|c|}{ Minimum Temperature } \\
\hline & \multicolumn{2}{|c|}{ Micro-pond } & \multicolumn{2}{|c|}{ Natural Pond } & \multirow[t]{2}{*}{ Ambient } & \multicolumn{2}{|c|}{ Micro-pond } & \multicolumn{2}{|c|}{ Natural Pond } & Ambient \\
\hline & $5 \mathrm{~cm}$ & $10 \mathrm{~cm}$ & $5 \mathrm{~cm}$ & $10 \mathrm{~cm}$ & & $5 \mathrm{~cm}$ & $10 \mathrm{~cm}$ & $5 \mathrm{~cm}$ & $10 \mathrm{~cm}$ & \\
\hline 26-Jul & 32.0 & 29.0 & 29.0 & 26.0 & 33.6 & 30.0 & 28.5 & 28.0 & 27.0 & 26.5 \\
\hline 27-Jul & 33.0 & 31.5 & 31.0 & 29.0 & 33.8 & 29.0 & 28.0 & 28.0 & 27.0 & 26.5 \\
\hline 28-Jul & 34.0 & 32.0 & 32.0 & 29.0 & 33.4 & 29.5 & 28.5 & 28.0 & 28.0 & 27.2 \\
\hline 31-Jul & 39.0 & 35.0 & 31.0 & 30.0 & 35.5 & 31.0 & 30.0 & 28.0 & 28.0 & 27.0 \\
\hline 1-Aug & 35.0 & 33.0 & 30.0 & 29.0 & 35.0 & 30.0 & 29.0 & 28.0 & 27.0 & 28.5 \\
\hline 2-Aug & 33.0 & 31.0 & 31.0 & 29.0 & 36.1 & 30.0 & 29.5 & 28.0 & 27.0 & 29.0 \\
\hline 3-Aug & 33.0 & 31.0 & 30.0 & 28.0 & 34.2 & 30.0 & 29.0 & 28.0 & 27.0 & 27.0 \\
\hline 4-Aug & 28.5 & 31.0 & 29.0 & 27.0 & 32.6 & 30.0 & 29.0 & 27.0 & 27.0 & 27.3 \\
\hline 5-Aug & 29.0 & 28.0 & 30.0 & 28.0 & 33.2 & 29.0 & 28.0 & 28.0 & 27.0 & 25.8 \\
\hline
\end{tabular}


Table.2 Economic performance of the micro-pond ( 2 decimal area) having the capacity of retting 1 acre jute for in-situ jute retting including its allied activities as per current (2019) price

\begin{tabular}{|c|c|c|c|}
\hline Sl. No & Particulars & Retting Micro-pond & Traditional Retting \\
\hline A. & Capital Cost & & \\
\hline 1 & Micro-pond excavation & 4300 & 0 \\
\hline 2 & $\begin{array}{l}\text { Tarpaulin / Silpaulin Sheet }(32 \mathrm{ft} \times 30 \\
\mathrm{ft})\end{array}$ & 8000 & 0 \\
\hline \multirow[t]{2}{*}{3} & Empty Cement bags (50 No) & 200 & 200 \\
\hline & $\underline{\text { Total Capital Cost }}$ & 12500 & 200 \\
\hline B. & Recurring Cost & & \\
\hline 1 & Sheet Laying, Removal and aftercare & 300 & 0 \\
\hline 2 & $\begin{array}{l}\text { Cost of Retting Culture Development } \\
\text { with Supplementary materials }\end{array}$ & 400 & 0 \\
\hline 3 & Cost of Transportation of jute bundles & 0 & $\begin{array}{l}12 \text { man-days yr }^{-1} @ \\
\text { Rs } 250=\text { Rs } 3000\end{array}$ \\
\hline 4 & $\begin{array}{l}\text { Cost of maintenance of the micro- } \\
\text { pond ( } 1 \text { man-day } \mathrm{yr}^{-1} \text { from } 2^{\text {nd }} \text { year } \\
\text { onward) }\end{array}$ & 0 & 0 \\
\hline 5 & Irrigation Cost & $\begin{array}{l}2 \text { hrs motor pumping } \\
@ \text { Rs } 100=\text { Rs } 200\end{array}$ & $\begin{array}{l}30 \mathrm{hr} \text { motor pumping } \\
@ \mathrm{Rs}=\mathrm{Rs} 3000^{*}\end{array}$ \\
\hline 6 & $\begin{array}{l}\text { Cost of Fish Farming including Lime, } \\
\text { Potassium permanganate for } \\
\text { conditioning of micro-pond retted } \\
\text { water }\end{array}$ & Rs 1500 & 0 \\
\hline \multirow[t]{3}{*}{7} & Cost of Vegetable Farming & Rs 1000 & 0 \\
\hline & Total Recurring Cost & 3400 & 3000 \\
\hline & Total Cost & 15900 & 3200 \\
\hline C. & Income & & \\
\hline 1 & Income from 2 decimal land jute & 0 & 1600 \\
\hline 2 & $\begin{array}{l}\text { By sale of higher grade fibre ( } 12 \mathrm{q} \\
\left.\text { acre }^{-1}\right) @{\mathrm{Rs} 200 \mathrm{q}^{-1}}\end{array}$ & Rs 3600 & 0 \\
\hline 3 & By sale of fish & 3000 & 0 \\
\hline 4 & By sale of vegetables & Rs 5000 & 0 \\
\hline 5 & $\begin{array}{l}\text { By Sale of Jute Waste Manure from } \\
\left.\text { pond floor ( } 10 \text { bags @ Rs } 30 \text { bag }^{-1}\right)\end{array}$ & Rs 300 & 0 \\
\hline \multirow[t]{3}{*}{6} & $\begin{array}{l}\text { By sale of additional produce (Rice / } \\
\text { Vegetable) with retted wastewater }\end{array}$ & Rs 250 & 0 \\
\hline & Total Income & 12150 & 1600 \\
\hline & Profit & -3750 & -1600 \\
\hline
\end{tabular}

* calculations excluding the irrigation cost 
Table.3 Financial analysis of an operational micro-pond

\begin{tabular}{|l|r|r|r|r|r|}
\hline Particulars & I year & $\begin{array}{r}\text { II } \\
\text { year }\end{array}$ & III year & $\begin{array}{r}\text { IV } \\
\text { year }\end{array}$ & $\begin{array}{r}\text { V } \\
\text { year }\end{array}$ \\
\hline Cost: & 12500 & & & & \\
\hline Capital Cost & 3400 & 4015 & 4420 & 4859 & 5359 \\
\hline Recurring cost & $\mathbf{1 5 9 0 0}$ & $\mathbf{4 0 1 5}$ & $\mathbf{4 4 2 0}$ & $\mathbf{4 8 5 9}$ & $\mathbf{5 3 5 9}$ \\
\hline Total Cost & & & & & \\
\hline Benefit: & 12150 & 13365 & 14779 & 16190 & 17808 \\
\hline Direct Income from micro-pond & -3750 & 9350 & 10359 & 11331 & 12449 \\
\hline Direct Benefits from micro-pond & 1600 & 1540 & 1694 & 1864 & 2050 \\
\hline $\begin{array}{l}\text { Indirect Benefit (Savings by avoiding } \\
\text { traditional Retting) }\end{array}$ & & & & & \\
\hline Net Benefits & $\mathbf{- 2 1 5 0}$ & $\mathbf{1 0 8 9 0}$ & $\mathbf{1 2 0 5 3}$ & $\mathbf{1 3 1 9 5}$ & $\mathbf{1 4 4 9 9}$ \\
\hline
\end{tabular}

Fig.1 Jute retting method and fibre quality comparison: (A) traditional retting in the roadside ditch, (B) 'shyamla' coloured fibre in traditional retting, (C) in-situ retting in tarpaulin-lined micro-pond with native microbial inoculum, and (D) golden coloured and lustrous fibre in micro-pond

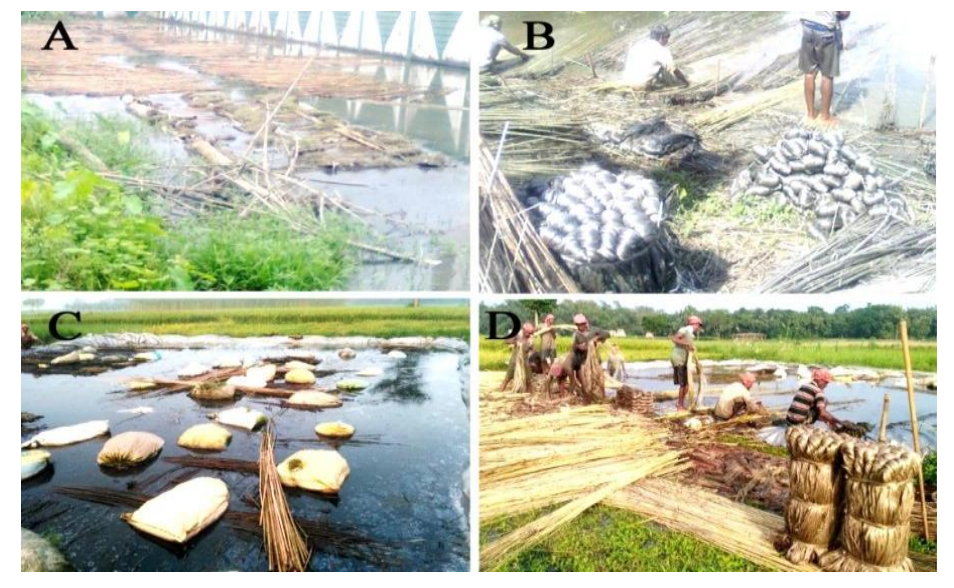

Fig.2 Construction and design of a circular in-situ micro-pond

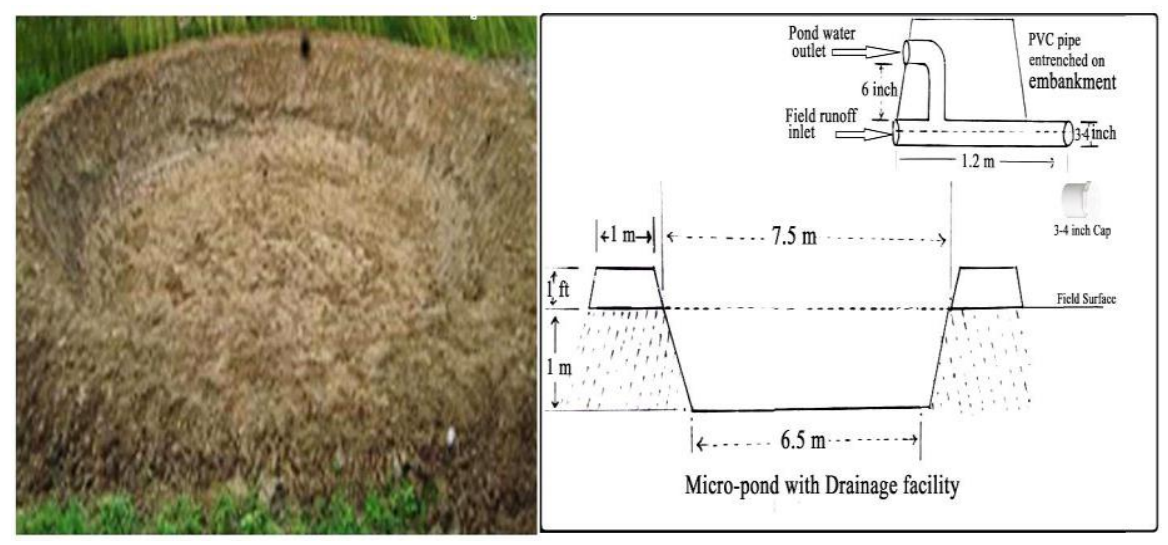


Fig.3 (A) Bare / Unlined micro-pond with a channel at its lower end and (B) tarpaulin-lined micro-pond for in-situ jute retting with harvested rainwater or groundwater at ICAR-CRIJAF, Barrackpore, India
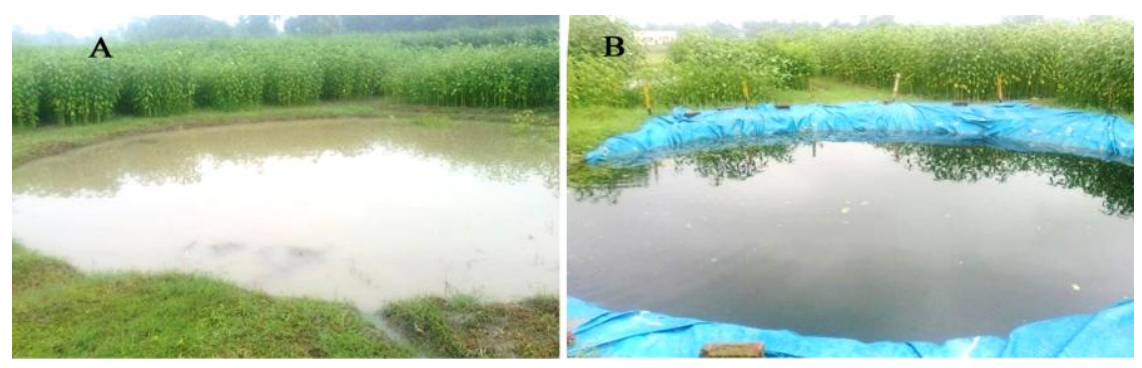

Fig.4 Retting of jute in shallow pit with ground water under extreme water scarcity:(A) conventional retting in bare shallow pit, (B) laying of LDPE sheet and sunnhemp leaves, (C) arrangement of jute bundles, (D) steeping in shallow pit and (E) in-situ retting in a rectangular lined shallow pit (90 cm deep) at farmers' field, Badshanagar, Nowda, Murshidabad District, West Bengal, India (2015 and 2019)

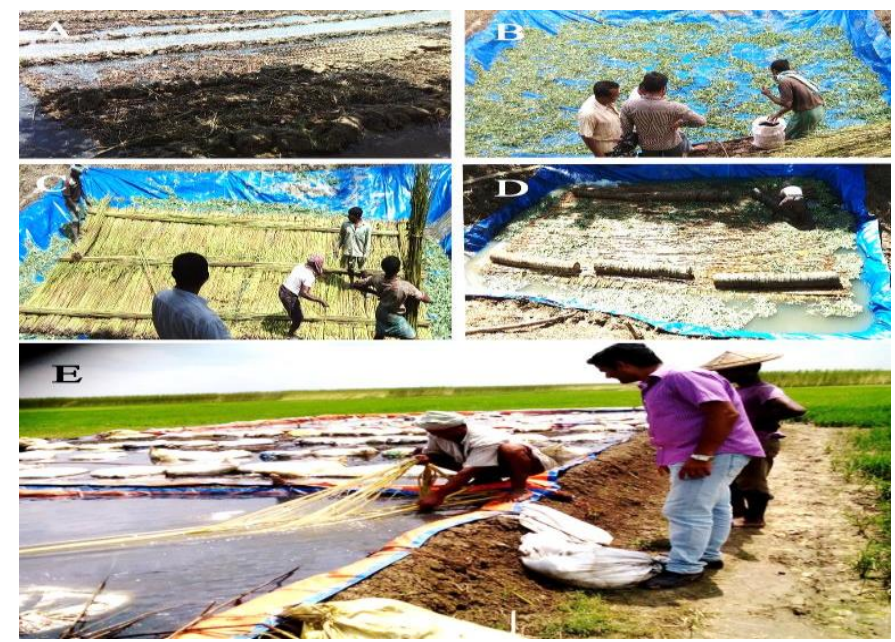

Fig.5 Native retting culture development 4 days ahead of retting using activators: (A) sunnhemp crop at 35 DAS around the pond and (B) soil from natural retting tank mixed with micro-pond water and supplemented with molasses, chopped off succulent sunnhemp plants, NPK (10:26:26) and Ammonium sulphate

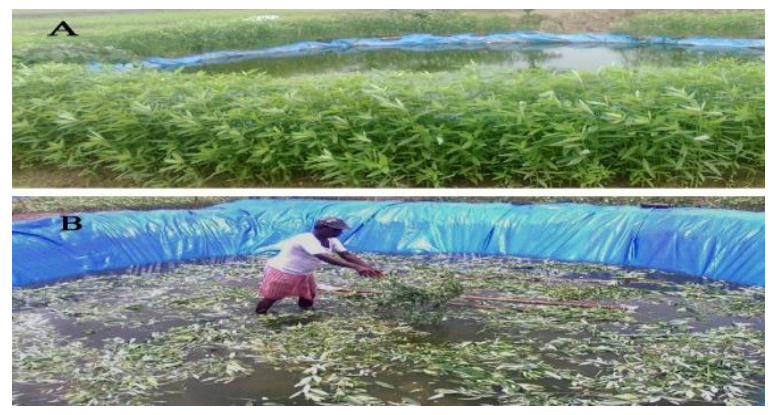


Fig.6 Operational sequences of steeping in micro-pond: (A) radial arrangement of jute bundles in the first layer with plant bottoms at 12-18 inch away from the pond periphery and placement of

few small bundles between layers, (B) second layer with placement of bundles in opposite direction to the first layer with plant tops laid extended by 12-18 inches towards pond periphery over bases of the first layer, (C) third layer as repetition of the first layer, (D) rice straw cover over bundles and placement of bamboos for uniform load distribution, (E) soil-filled cement bags as loads placed on bamboos for steeping, and (F) water filled to the brim for retting
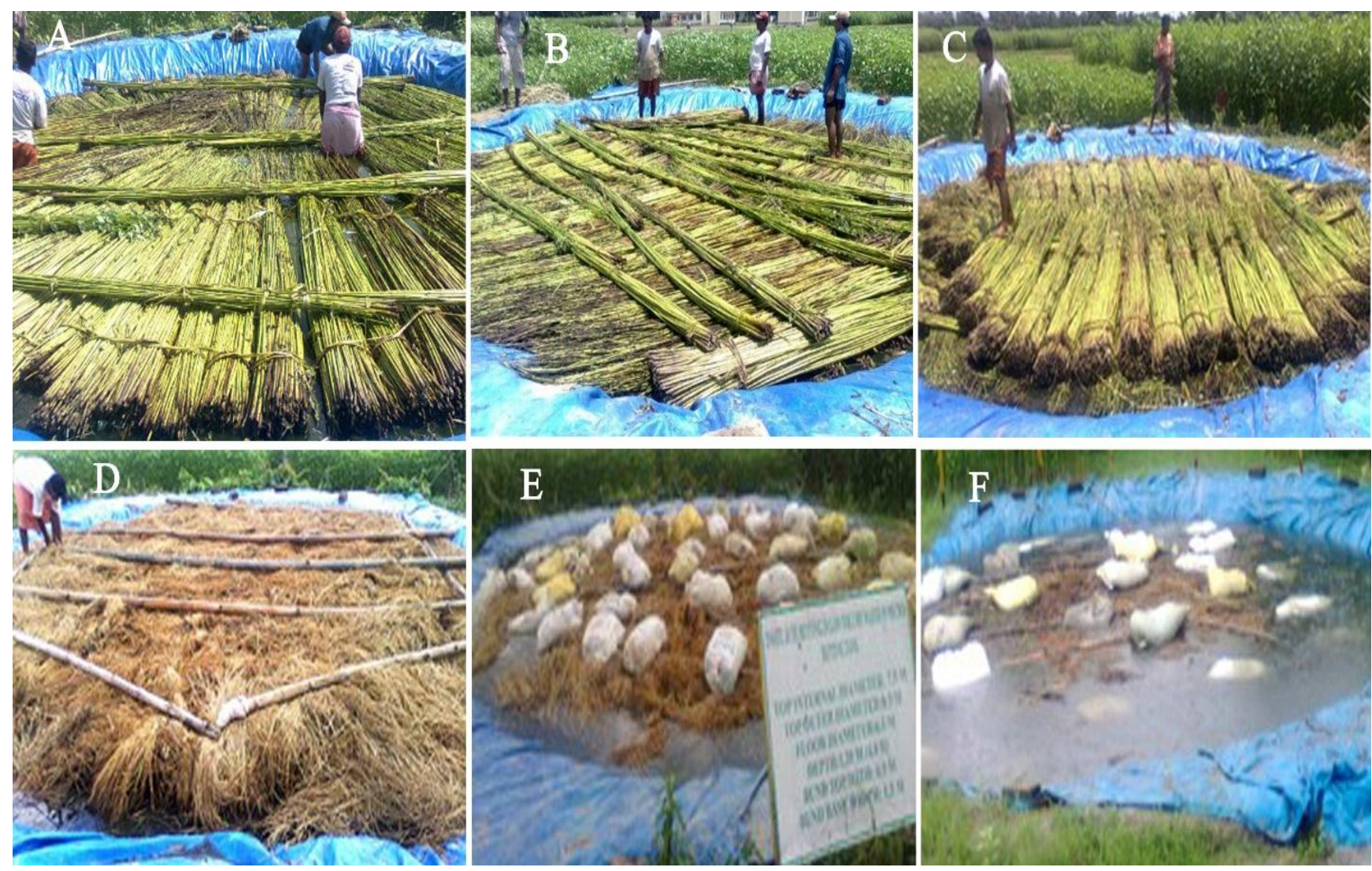

Fig.7 Water-filled mega plastic bags for steeping jute bundles

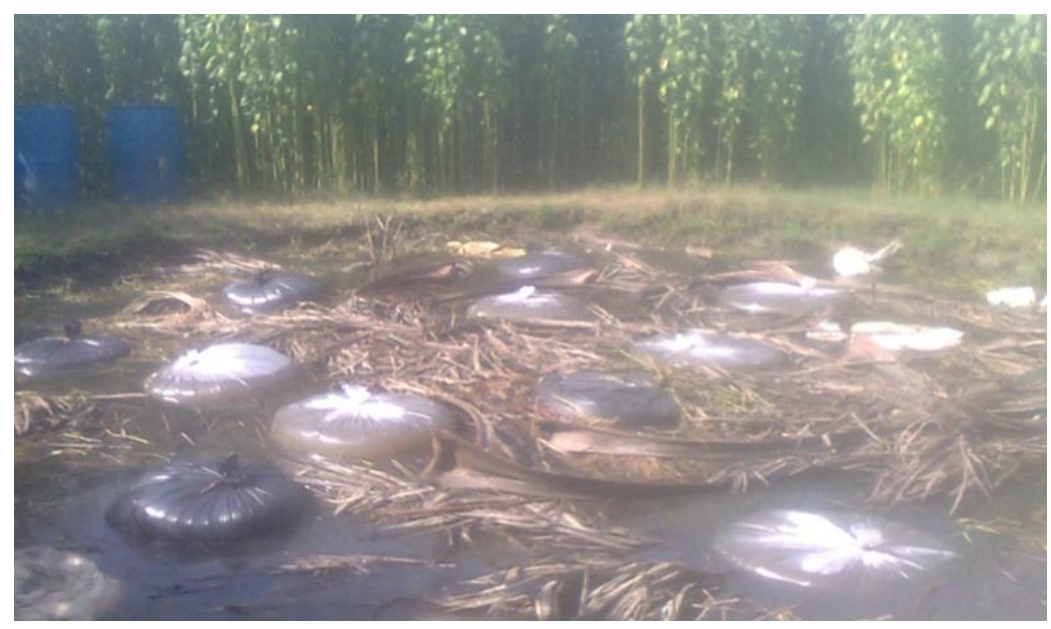


Fig.8 Field demonstration ( 1 acre $=\mathbf{0 . 3 3}$ ha jute crop area) of retting and fibre extraction in a tarpaulin-lined micro-pond FIAC (2019) at Chapra, Nadia, WB: (A) ready for fibre extraction on completion of retting (scum on the water surface), (B) pumping freshwater into the pond through one side, removal of weight materials for floating jute bundles, (C) draining out of retting wastewater containing ferrous-tannate through another side of the pond, (D) extraction in group in a comfortable and hygienic condition by squatting over the tarpaulin-lined bund and (E) washed golden coloured and lustrous fibre bundles and piled up jute sticks around the pond

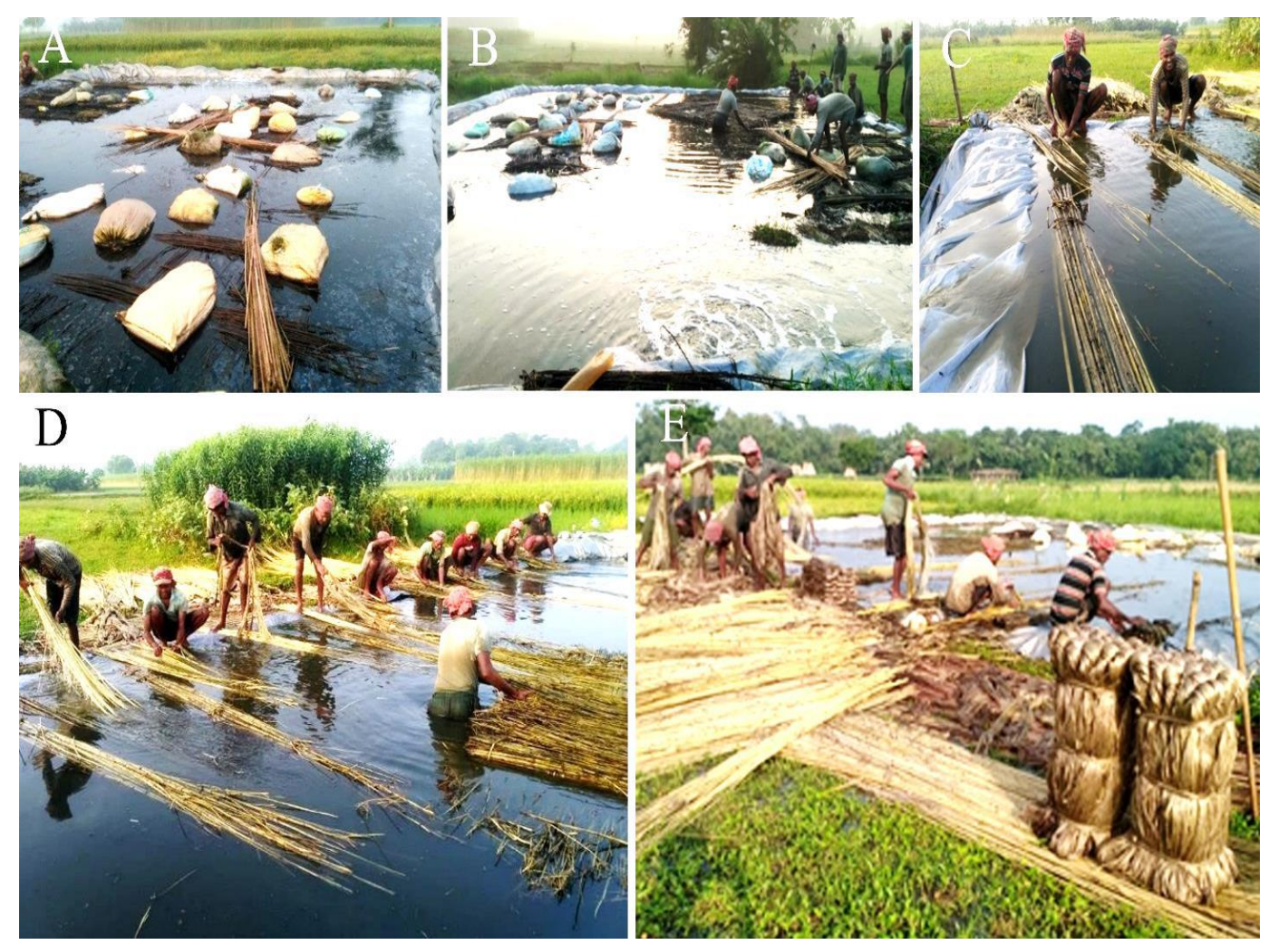

Fig.9 Removal of silpaulin/polyethylene sheet from the pond and cleaning in the micro-pond

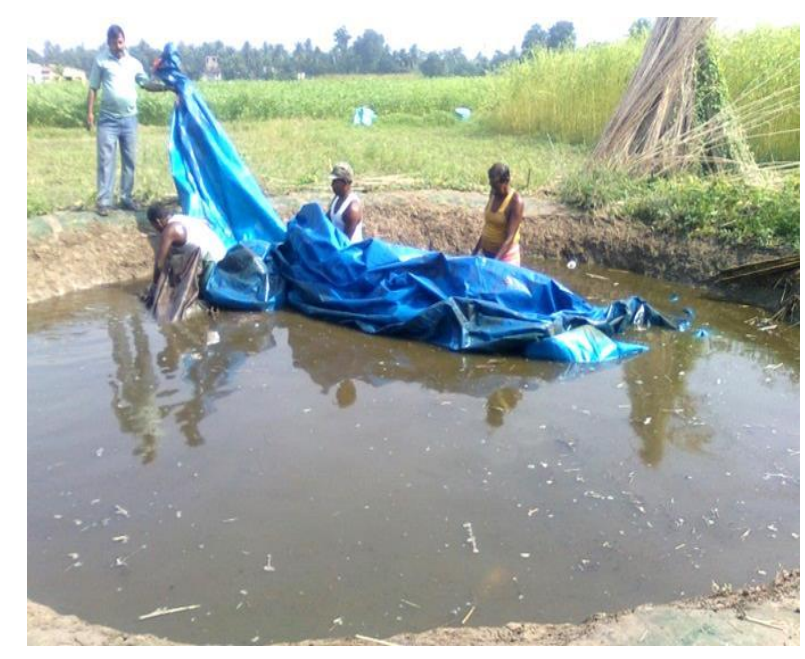


Fig.10 Use of pond area and retting wastes in crop production: (A) broccoli grown on bund, (B) brinjal and dioscorea (Dioscorea alata) grown on bund, (C) cabbage grown on pond floor, (D) summer rice grown on pond floor, (E) basil leaf and snake gourd grown on bund and retting waste manure collection from pond floor and $(\mathrm{F})$ draining out of tanned retted water to irrigate adjacent rice plot
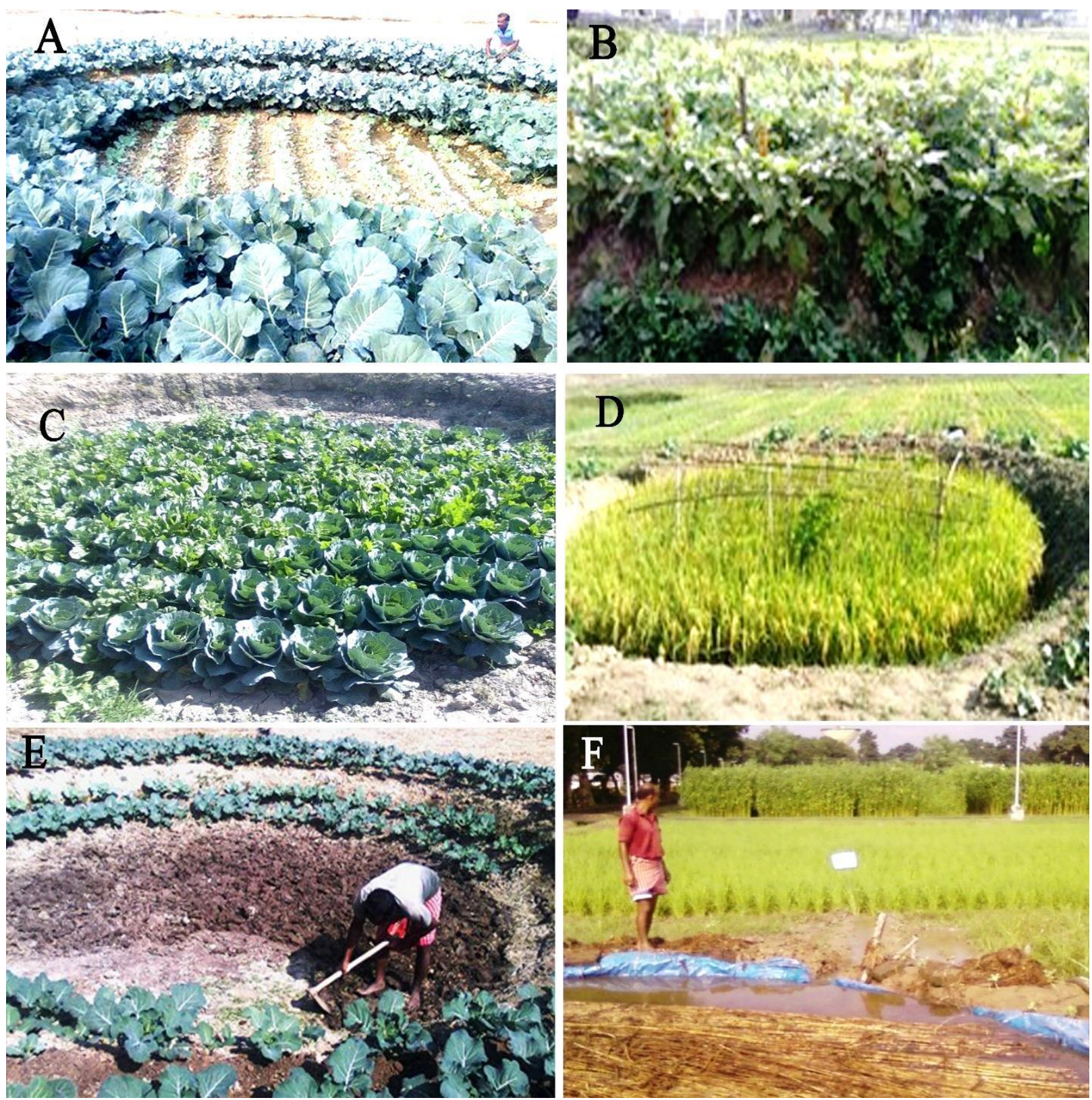
Fig.11 Inconveniences in steeping and fibre extraction operations in presence of crops grown around bund of the micro-pond: (A) bulky jute bundles stacked around micro-pond and (B) piled up wet jute sticks and fibre bundles over plants around micro-pond and damage of existing crops (Year 2011)
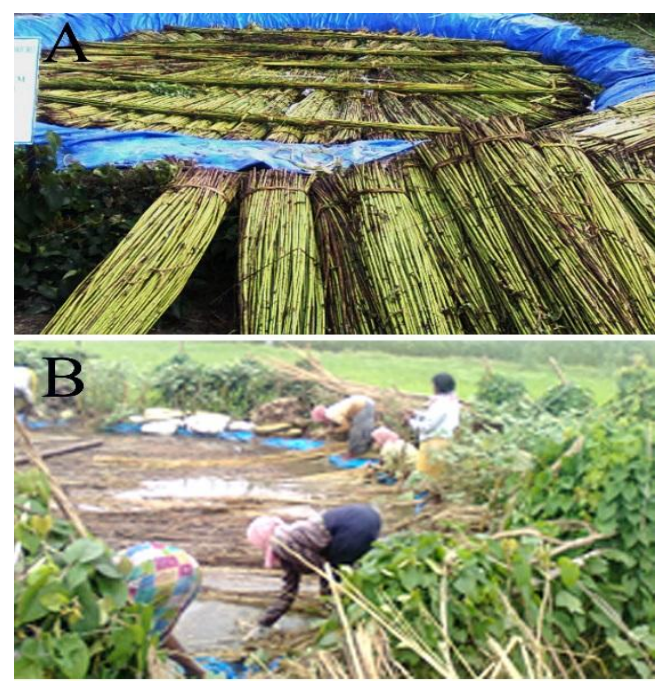

Fig.12 Catches of fishery in post-retting water of a micro-pond:(A) singhi (Heteropneutes fossilis) and magur (Clarias gariepinus), (B) walking fish (Clarias batrachus) and tilapia (Tilapai spp), and (C) rohu (Labeo rohita)
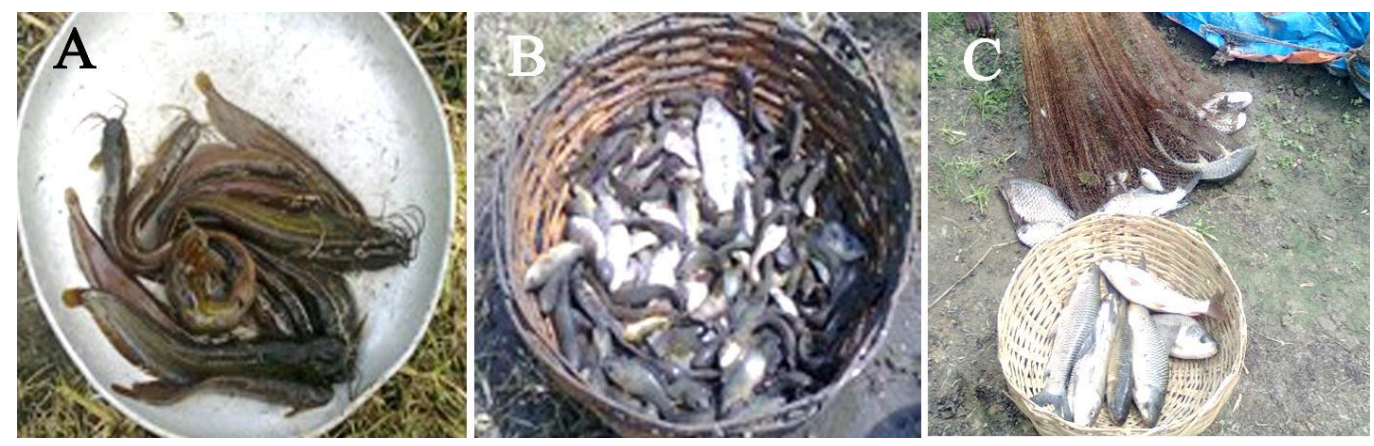

Fig.13 Drainage of excess rainfall into micro-pond excavated for in situ jute retting to rescue germinating jute field from an early waterlogging damage (2020) at ICAR-CRIJAF, WB, India

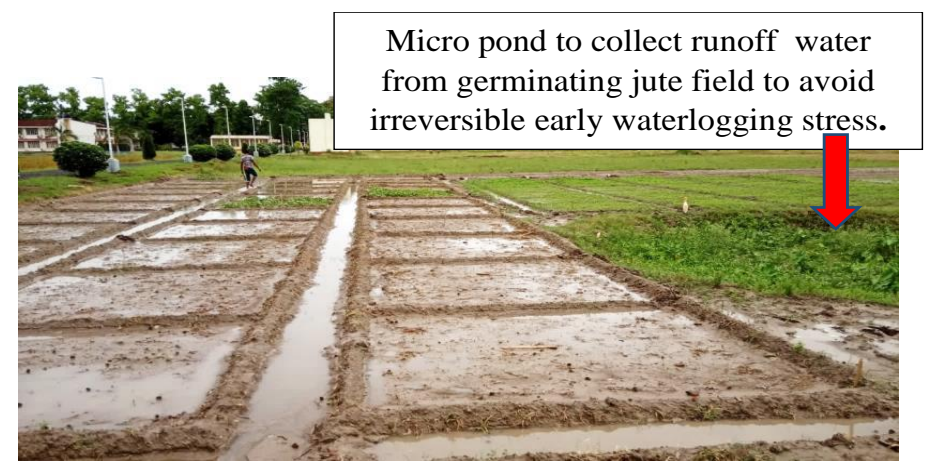


Figure.14 Workflow diagram of in-situ jute retting using native microbial inoculum, retting waste management and integrated vegetable-fish farming. Light orange boxes are activities on one-day prior to jute harvesting and light green boxes are activities on the day of jute harvesting.

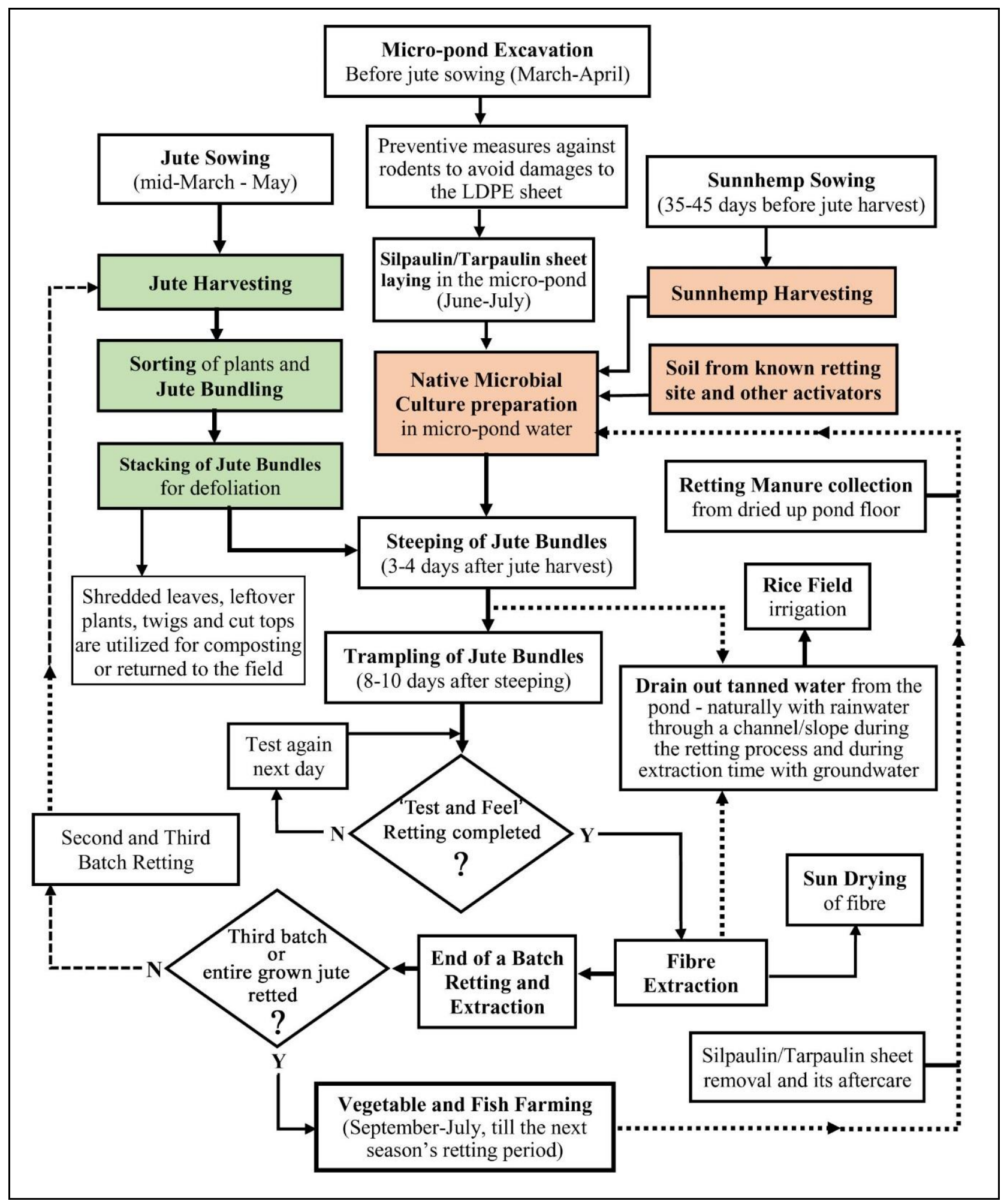


In the pre-retting period, production of all native fresh water fishes was successful. Selective air-breathing fishes were cultured during initial post-retting days, depending on the quality of the jute retting water. To hasten fish farming in the post-retting period required conditioning of degraded water.

Immediately after fibre extraction, conditioned the pond water by the application of lime@ $1 \mathrm{~kg}$ per pond, for increasing dissolved oxygen level of water, transparent water through settlement of suspended impurities to the pond base and reducing microbial load of jute retted water (http://www.fao.org/fishery/static/FAO_Train ing/FAO_Training/General/x6709e/x6709e05 $. \mathrm{htm})$. It was in addition to $2 \mathrm{~kg}$ lime applied during extraction. After a wait of 15 days, freshwater species were cultured in the pond.

\section{Integrated high-value vegetable production in the pre-retting and post-retting periods}

Fifteen days after fibre extraction, vegetable production was initiated on the pond embankment. Cauliflower, broccoli, basil leaf, Dioscorea, brinjal, snake gourd, papaya and other vegetables were planted. Vegetables were managed as per recommendations. In the pond floor, cabbage, spinach and summer rice (Figure 10D) were grown. Vegetable cultivation continued until the jute retting for the next season ensued. It increased net return by Rs. 5000 from marketing of grown vegetables in and around the micro-pond. Whereas, the return from usual jute-rice-rice cropping system is only Rs. 1500 (Ghorai, et al., 2013).

\section{Integrated fish farming in the pre-retting and post-retting periods}

After removal of silpaulin or polythene sheets, air-breathing fishes like, cat fish i.e singhi (Heteropneutes fossilis) and magur
(Clarias gariepinus), tilapia (Tilapai spp.), walking fish (Clarias batrachus) were grown in the post-retting pond water (Figure 12A and B). In some years, it was also used as nursery tank for rearing of fish fingerlings (45 inches long) of major carp. The major carps, rohu (Labeo rohita) stocked in the tarpaulinlined micro-pond with initial average weight of 150-200 g gained weight upto 600-700 $\mathrm{g}$ in eight months (Figure $12 \mathrm{C}$ ) by feeding with kitchen wastes. The performance of bata (Labeo bata) was very satisfactory in tarpaulin-lined micro-pond. A harvest of 15 $\mathrm{kg}$ fish in 5 months (March to July) of preretting water was possible (Ghorai et al., 2013).

\section{Additional uses of in situ jute retting tanks}

Apart from jute retting and other utilities discussed above, the tanks can have the following other multipurpose uses.

i) The in-situ jute retting tanks $(12 \mathrm{~m} \times 10 \mathrm{~m}$ $\times 1.35 \mathrm{~m}$ ) will save the jute crop from an early waterlogging stress by runoff collection from jute field with a maximum of $120 \mathrm{~mm}$ rainfall in a day. Now-a-days, this type of excessive rainfall is a common phenomenon due to current climatic changes. Crop loss is also common in crops (green gram, sesame, miaze etc) due to sudden waterlogging during summer months from nor'wester rain. Germinating jute crop of $1 / 3$ will also work as percolation tanks for acre of an experimental plot was drained out and saved the plot from early waterlogging stress by collecting its surface runoff in a $120 \mathrm{~m}^{2}$ micro-pond during excessive rainfall of 2020, in which the plot received $69 \mathrm{~mm}$ rainfall on an irrigated germinating jute crop (Figure 13). ii) In a lined pond or an unlined pond with clay soil, water can be retained and lifesaving irrigations can be given from micro-ponds in post-retting period to rice-rabi crops. iii) Micro-retting tanks in rice fields will also 
work as percolation tanks for groundwater recharge which have become very popular methods of managed aquifer recharge due to their low cost, ease of construction and the participation and assistance of community (Christy and Lakshmana, 2017). In terms of depth, around $45 \mathrm{~cm}$ to $60 \mathrm{~cm}$ water percolates down every day (i.e., nearly 54000 720001 day $^{-1} \mathrm{ha}^{-1}$ ) from unlined retting tank in alluvial soil. In jute growing belts, the annual rainfall varies from $1200 \mathrm{~mm} \mathrm{yr}^{-1}$ in South Bengal to $2500 \mathrm{~mm} \mathrm{yr}^{-1}$ in North Bengal. Considering $40 \%$ as runoff of the total rainfall in a year, annually around 48 to 100 lakh litre water per ha from jute field can be recharged to the unconfined aquifer through these dugout ponds (Ghorai, 2019). iv) In the experiment utilized the empty jute retting tank during dry months for composting of wheat/ rice/mustard straw to save these bio resources from field burning (Ghorai, 2020).

\section{Comparative economic performance of in- situ jute retting over conventional retting}

Total investment in a 2 decimal area $\left(80 \mathrm{~m}^{2}\right)$ in-situ retting micro-pond, to ret 1 acre jute area, using tarpaulin sheet was Rs. 15900 as per current (2019) price, inclusive of all associated activities (Table 2). Whereas, in the traditional retting system the cost was Rs. 3200, excluding the usual irrigation cost. Total income from this jute retting and polyculture system was Rs.12150, in the first year. Assuming yearly $10 \%$ price escalation, the net return of the system will vary from Rs 13365 to Rs. 17607 during its second to fifth year (Table 3). Whereas, the gross income was only Rs.1600 in traditional jute-rice-rice cropping system from 2 decimal plot during the first year. The benefit cost ratio was 1.20:1 It did not take account the monetary gain on ecology and increased soil carbon sequestration from waste recycling. This higher revenue is generated by i) elimination of transportation cost of jute bundles to distant retting spots, ii) obtaining fibre of higher grade of higher market value from the system, iii) return from vegetables grown on the embankment and dried pond, iv) return from the post-retting fish farming in the retting tank, v) 10-15 bags of solid waste manure for crop manuring, and vi) utilization of the nutrient-rich drained out retted wastewater of the pond to irrigate local scented rice cv. Chini Atap (price Rs.2000 $\mathrm{q}^{-1}$ ) plot, grown in a plot adjacent to the retting pond that increased rice yield by $1 \mathrm{q}$ $\mathrm{ha}^{-1}$ compared to that with groundwater.

In conclusion and implication, in-situ jute retting is a worthwhile alternative to the traditional ex-situ retting. This technology is a definitive strategy of jute retting with agronomic, environmental, economic and human health benefits by integrating few component enterprises of farming system. It fits well within the traditional rural farming systems favouring the existing socioeconomic, cultural and environmental conditions of the jute growing region. Obviously, limitations of the location of the pond, its size and health risks of waste water for this micro-pond based new IFS model, exceptionally disfavours integration of livestock component of usual homestead pond based IFS. Barring the retting period of 11/2-2 months, production of selective annual crops, vegetables, fruits and short period fish farming, particularly air-breathing cat fishes, are minimizes water requirement for jute retting (1:1.20) over conventional method (1:20) and addresses the problem of water scarcity during retting, reduces drudgery and transport cost of jute bundles to distant water bodies, assures retting to produce quality jute fibre with higher price (Rs. $300 \mathrm{q}^{-1}$ ) and creates a moderately hygienic condition of fibre extraction than conventional method. It reduce transitory pollution load on natural water bodies and conserve retted wastewater and rich solid organic matter (10-15 bags per 
season per acre) for agronomic use and fishery. Water use efficiency in micro-pond retting is much higher (>90\%) over conventional retting. It will be of immense help to the jute farmers for light textured soil and in drought condition (under deficit rainfall or water scarcity situation), in particular. Additionally, a well-developed network of in-situ jute retting tanks in IndoBangla subcontinent can function as percolation tanks to improve groundwater recharge, water reservoir for lifesaving irrigations, land surface catchment to harvest surface run off for saving field crops (jute, sesame, green gram and black gram) from early waterlogging stress under changing climatic scenario and in-situ composting pits during dry months (Fig. 14).

\section{Acknowledgements}

The authors acknowledge the financial assistance of ICAR in the Technology Mission on Jute Mini Mission-I project and the help of the Directors of ICAR-CRIJAF during the course of investigations. Authors also acknowledge the support of Department of Agriculture, Government of West Bengal, Mr. Ramprosad Ghosh and Dr. Pranab Kumar Hembram in particular and Nodal Officer of NFSM (CC)-Jute, Dr. C S Kar, ICARCRIJAF, for demonstration of jute retting in different districts of West Bengal. The authors are indebted to AINP JAF-CRIJAF for dissemination of the technology in different jute and mesta growing states of the country. The authors thank the ADAs of Dept. of Ag., Govt. of WB, farmers and staff of Crop Production Division at the ICAR-CRIJAF for their support and field and lab assistance.

\section{References}

Ahmed, M. (1992).Status and potential of aquaculture in small waterbodies (ponds and ditches) in Bangladesh. International Center for Living Aquatic Resources
Management (ICLARM) Tech. Rep. 37, $36 \mathrm{p}$.

Ahmed, Z. and F. Akhtar (2001). Jute retting: An Overview. Online J. Biol. Sci. 1(7): 685-688.

Banerjee, S. and M. G. Dastidar (2005). Use of jute processing wastes for treatment of wastewater contaminated with dye and other organics. Bioresour. Technol. 96(17): 1919-1928. doi:10.1016/j.biortech.2005.01.039

Banik, S., M.K. Basak, D. Paul, P. Nayak, D. Sardar, S.C. Sil, B.C. Sanpui and A. Ghosh (2003). Ribbon retting of jute - A prospective and eco-friendly method for improvement of fibre quality. Ind. Crop, Prod. 17(3):183-190.doi: 10.1016/S09266690(02)00097-3

Bhattacharyya, S.K. (1974). Retting of jute-A key process that needs more attention. Jute Bull 36: 194-198.

Christy, R.M. and E. Lakshmanan (2017). Percolation pond as a method of managed aquifer recharge in a coastal saline aquifer: A case study on the criteria for site selection and its impacts. J Earth Syst. Sci. 126: 66. doi: 10.1007/s12040-0170845-8

Das, B., K. Chakrabarti, S. Tripathi and A. Chakraborty (2014). Review of some factors influencing jute fiber quality. J. Nat. Fibers 11(3): 268-281.

Dasgupta, P.C., D. Sardar and A.K. Majumdar (1976). Chemical retting of jute.Food Farm. Agric. 8:7-9.

FAO (1998). Improved retting and extraction of jute. Terminal report; AG: GCP/RAS/122/IJO.

FIAC (2019). Modern technique of in situ jute retting in low volume water.(Kam Jale Pater Jomite Pat Pochanor Adhunic Paddhati). Leaflet in Bengali. Farm Information Advisory Centre Chapra, Nadia, Dept. of. Ag., Govt. of WB, 2 p.

George, R. (2015). The economic lives of smallholder farmers: An analysis based on household data from nine countries. FAO, Rome. http://www.fao.org/3/a-i5251e.pdf

Ghorai, A.K. (2019). Ground water recharge 
and lifesaving irrigation potential of dugout ponds for in-situ jute retting in rice paddies. https://www.researchgate.net >publication

>335757494 Ground water rec.doi:

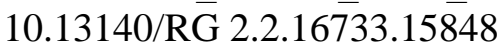

Ghorai, A.K. (2020). In situ enriched compost preparation from rice and wheat straw using tender sunnhemp to minimise field burning. Int.J.Curr.Microbiol.App.Sci. 9(09): 627-633.

doi: 10.20546/ijcmas.2020.909.079

Ghorai, A.K., H. Chowdhury, D.K. Kundu, Mukesh Kumar, D. Barman, B.S. Mahapatra and M.K. Tripathi (2013).Insitu jute (Corchorusolitorius L.) retting in low volume water in polyethylene lined micro pond using native culture and poly culturein and around it. ICAR-CRIJAF Research Bull. No. 6/2013

Ghorai, A.K., S. Saha, B.K. Saren, P.K. Hembram, K. Mondal, H. Chowdhury and B.S. Mahapatra (2010). Drought management for jute and jute based cropping systems under deficit rainfall in changing climatic scenario. (Leaflet, CRIJAF) P-8.

Ghorai, A.K., A.K. Chakraborty, N.C. Pandit and A.K. Jana (2003a). Insitu retting of jute (Corchorus olitorius L.) and Mesta (Hibiscus cannabinus). JafNews 1(2):7-8.

Ghorai A.K., N.C. Pandit, S. Samanta and A.K. Chakraborty (2003b). Concentrated manures from jute and mesta leaves. SAIC Newsletter, 13(2): 6 and 9.

Ghorai, A.K., S. Saha and A.K. Chakraborty (2014). Concentrated jute and mesta leaf manures: Its role on summer radish production and its comparative performance with mustard oil cake. IndoAmerican Journal of Agriculture and Veterinary Sciences. 2(1): 26-30.

Ghosh, D. and J.K. Biswas (2015). Impact of jute retting on native fish diversity and aquatic health of roadside transitory water bodies: an assessment in eastern india. $\mathrm{J}$ Ecol. $\quad$ Engg. $16 \quad$ (4): 14 21.doi:10.12911/22998993/59342
Ghosh, S.N. and R.G. Bose (1973). Biodeterioration of jute. J. Text. Assoc. 34: 11-16.

Haque, M.S., Z. Ahmed, F. Akhter, M. Asaduzzaman, M.M. Rahman and M.A. Hannan (2001a). Comparative studies of retting properties of different released varieties of jute. Online J. Biol. Sci. 1: 998-1000.

Haque M.S., M. Asaduzzaman, F. Akhter, M.A. Samad, T. Baksh and Z. Ahmed (2001b).Effect of nature of harvest of jute plants on the production of cuttings and improvement of fibre quality. Online $\mathrm{J}$. Biol. Sci. 1: 563-564.

Haque, M.S., Z. Ahmed, Md. Asaduzzaman, M. A. Quashem and Firoza A. (2002).Distribution and activity of microbial population for jute retting and their impact on water of jute growing areas of Bangladesh. PJBS 5: 704-706. doi: 10.3923/pjbs.2002.704.706

Jarman, C.G. (1985). The retting of Jute. FAO Agriculture Organization of the United Nations, Viadelle Terme di Caracalla, Rome, Italy, pp 1-54.

Kumar, M. and P.K. Padhy (2015). Environmental perspectives of pond ecosystems: Global Issues, Services and Indian Scenarios. Curr. World Environ. 10(3): 848-867. doi: 10.12944/CWE.10.3.16

Majumdar, A.K. and A. Day (1977). Chemical constituents of jute ribbon and the materials removed by retting. Food Farm. Agric. 21:25-26.

Mandal, A. (2016). Comparative study of marginal farms in India vis-a-vis West Bengal; Evidences from last decade. Economic Affairs 61(4): 589-598.

Mondal, D.K., and A. Kaviraj (2008). Ecotoxicological effects of jute retting on the survival of two freshwater fish and two invertebrates. Ecotoxicology 17(3): 207-211. doi:10.1007/s10646-007-01856

Munshi, T.K. and B. B. Chattoo (2008).Bacterial population structure of the jute-retting environment. Microb. 
Ecol. 56(2): 270-282. doi: 10.1007/s00248-007-9345-8

Thi Da, C., P. Anh Tu, J. Livsey, V.T. Tang, H. Berg, and S. Manzoni (2020). Improving productivity in integrated fish-vegetable

farming systems with recycled fish pond sediments. Agronomy, 10(7): 1025. doi: 10.3390/agronomy10071025

\section{How to cite this article:}

Asesh Kumar Ghorai and Asim Kumar Chakraborty. 2020. Sustainable In-situ Jute Retting Technology in Low Volume Water using Native Microbial Culture to Improve Fibre Quality and Retting Waste Management. Int.J.Curr.Microbiol.App.Sci. 9(11): 1080-1099.

doi: https://doi.org/10.20546/ijcmas.2020.911.126 